Images in...

\title{
Right coronary artery fistula to right ventricle
}

\author{
Umar Imran Hamid, Harry Parissis \\ Department of Cardiothoracic Surgery, Royal Victoria Hospital, Belfast, UK \\ Correspondence to Umar Imran Hamid, umar79@hotmail.com
}

\section{DESCRIPTION}

A murmur was noted in a 2-year-old patient who was otherwise asymptomatic. The patient was born by caesarean section at 37 weeks gestation. No significant family history was present. Clinical examination revealed a continuous murmur at the sternal edge. Echocardiography did not reveal any abnormality. Cardiac catheterisation revealed a communication between the right coronary artery (RCA) and the right ventricle (RV).

On median sternotomy, a dilated tortuous acute marginal branch communicating with the RV was evident (figure 1). After placing the patient on cardiopulmonary bypass, the vessel was tied off with no associated haemodynamic compromise. Postoperative period was uneventful. Follow-up echocardiography showed good left ventricle function.

Coronary artery fistula (CAF) was first described by Krause in 1865. The congenital fistulous connections, between the coronary system and the cardiac chambers, are rare conditions that apparently represent the persistence of the embryonic and sinusoid intertrabecular spaces. Congenital CAFs account for only $0.27-0.4 \%$ of all congenital cardiac defects.

The aetiology of CAFs may be congenital, traumatic or iatrogenic, that is, after coronary intervention or valve replacement. Around $55-65 \%$ of congenital CAFs arise from the RCA and usually drain into a right chamber; a RCA into a left chamber is less frequent. ${ }^{1}$ The most prevalent receiving chamber of CAF (45\%) is the RV, followed by the right atrium (25\%) and the pulmonary artery $(20 \%){ }^{2}$

Children with CAF are generally asymptomatic; in adults a variety of complications may occur ranging from cardiac insufficiency, myocardial ischaemia, infective endocarditis, arrhythmias and rupture. ${ }^{3}$ Diagnosis of CAF is based on angiography. Echocardiographic examination may be helpful for diagnosis, usually demonstrating the drainage site and sometimes the dilated fistula itself.

In conclusion, RCA with RV drainage and giant coronary artery aneurysm are rarely seen in congenital CAF.

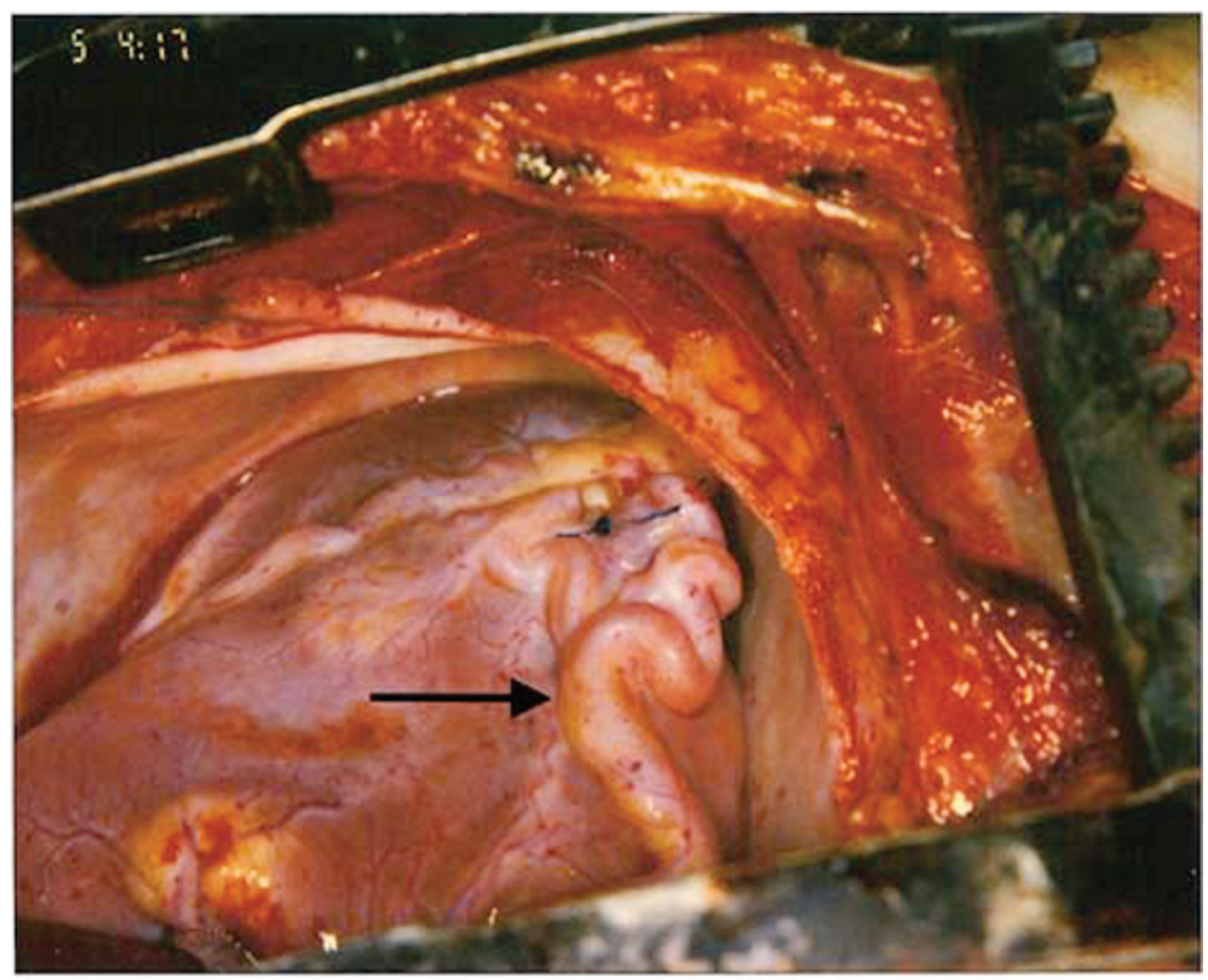

Figure 1 Arrow indicating the right coronary artery aneurysm communicating with the right ventricle. 


\section{BMJ Case Reports}

The optimal treatment for CAF should be coronary surgery, even in the asymptomatic patient.

Competing interests None.

Patient consent Not obtained.

\section{REFERENCES}

1. Wei J, Shu Y, Wei X, et al. Right coronary artery fistula to left

ventricle complicated with huge coronary artery aneurysm. Intern Med 2011;50:239-42
2. Kidawa M, Peruga JZ, Forys J, et al. Acute coronary syndrome or steal phenomenon - a case of right coronary to right ventricle fistula. Kardiol Pol 2009;67:287-90.

3. Ishii Y, Suzuki T, Kobayashi T, et al. Single coronary artery with right ventricular fistula: case report and literature review. Congenit Heart Dis 2010;5:56-9.

This pdf has been created automatically from the final edited text and images.

Copyright 2011 BMJ Publishing Group. All rights reserved. For permission to reuse any of this content visit http://group.bmj.com/group/rights-licensing/permissions.

BMJ Case Report Fellows may re-use this article for personal use and teaching without any further permission.

Please cite this article as follows (you will need to access the article online to obtain the date of publication).

Hamid UI, Parissis H. Right coronary artery fistula to right ventricle. BMJ Case Reports 2011;10.1136/bcr.03.2011.3941, date of publication

Become a Fellow of BMJ Case Reports today and you can:

- Submit as many cases as you like

- Enjoy fast sympathetic peer review and rapid publication of accepted articles

- Access all the published articles

- Re-use any of the published material for personal use and teaching without further permission

For information on Institutional Fellowships contact consortiasales@bmjgroup.com

Visit casereports.bmj.com for more articles like this and to become a Fellow 